\title{
THE ADAPTATION STRATEGIES OF A COMMUNITY'S FOOD PRODUCTION AND CONSUMPTION WITHIN A SMALL ISLAND ECOSYSTEM (A CASE STUDY AT KARAMPUANG ISLAND IN MAMUJU DISTRICT, WEST SULAWESI, INDONESIA)
}

\author{
Sulaiman ${ }^{1}$, M. Saleh S. Ali", Darmawan Salman² \\ ${ }^{1}$ Graduate School of Hasanuddin University, South Sulawesi, Indonesia \\ 2 Department of Social Economics of Agriculture, Faculty of Agriculture, Hasanuddin University, South \\ Sulawesi, Indonesia \\ * Corresponding author e-mail: saleh.assofie@gmail.com
}

Citation: Sulaiman., Ali, M.S.S., Salman, D. 2019. The Adaptation Strategies of A Community's Food Production and Consumption Within A Small Island Ecosystem (A Case Study at Karampuang Island in Mamuju District, West Sulawesi, Indonesia). J. Asian Rur. Stud. 3(2): 186-195

\begin{abstract}
Restricted production facilities for fishermen and marginal land ownership have triggerred low living standard for communities on small islands. This negatively impacts on community members' ability to fulfill household food needs. Therefore, long-term survival requires a pattern of adaptation by the social environment of the community. This study examines and analyzes the strategies of a single community's food production and consumption within an island ecosystem. Case study research was chosen in order to provide in-depth exploration and description of the adaptation patterns of the community's food production and consumption on Karampuang Island. The data were collected using in-depth interviews supplemented by focus group discussions and field observations in order to comprehensively explore the social and economic lives of community members. The results indicated that the adaptation strategies of the community's food production in Karampuang Island included a double livelihood strategy. Gendered division of labor was found to utilize the optimal potential of household workers: men were responsible to do fishing in the sea and work as wage laborers in Mamuju City while women were responsible for selling the fish to market in Mamuju City market, and worked as laundry women and shopkeepers. The food consumption adaptation strategy among people in Karampuang Island was accomplished by diversifying food between cassava and rice.
\end{abstract}

Keywords: Adaptation Strateg; Food Consumption; Food Production; Island Ecosystem

\section{Introduction}

Access to nourishing food is one of the most significant factors in determining the quality of life. Food has very complex dimensions, not only in terms of life and health, but also in social, cultural and political aspects. Therefore, the realization of food security and nutrition cannot be separated from efforts to improve the quality of health of individuals and communities, to increase the competitiveness of human resources, which eventually becomes the nation's competitiveness. Food can be regarded as a cultural product since it is the result of active adaptation between humans and their environment, entailing the fact that food security must rely on local resources and local 
wisdom. Thus, it can become a vehicle in the development of local and national culture (Suryana, 2011).

Local resources and local wisdom become a foundation in achieving food security. Food security is concerned with the availability and affordability of adequate and highquality food. In this case, there is an aspect of supply, which includes food production and food distribution (Krisnamurti, 2005). In addition to that, there is an aspect of purchasing power, which includes the level of income of individuals and households. There is also an aspect of accessibility of food, which relates to the opportunities for individuals and families to get food. Food security can be said to be achieved when every person or household has physical and economic consistent access to safe and nutritious food in quantities that meets their basic needs (Carletto, Zezza, \& Banerjee, 2013).

Different from agrarian societies (upland and lake areas), whose food availability and affordability relied upon local food production combined with distribution from the nearest centers (Ahmad et al., 2017; Ali, et el., 2017), coastal and small island communities rely much more on food supplied through market distribution because of their inability to produce food independently (Sulaiman, Ali, \& Salman, 2018). One result is that an individual's purchasing power greatly determines their ability to obtain adequate and good-quality food. The limited resource of the community on small islands becomes an obstacle to increasing their income, both of individuals and of households. Economic accessibility helps determine the ability of individuals or communities to access and limit food consumption. This ability is determined by the level of household income, which, in turn, significantly influences the budget allocation for food (Osman, Osman, Mokhtar, \& Setapa, 2014).

The basic function of food is to provide sufficient energy and nutrients in order to support bodily functions and physical activity. Therefore, a variety of foods are needed to adequately fulfill nutritional needs (Gerbens-Leenes \& Nonhebel, 2002). However, adequate nutrition generated from various types of food cannot be produced in all regions and cannot always be produced when needed. Thus, the efforts to diversify food consumption are needed to anticipate limited access of food and people's purchasing ability (Handewi, Rahman and Ariani, 2008).

Coastal areas located on small islands are isolated areas, which are often suffering from poverty, lack of information, poor education and knowledge (Sulistyowati, 2003). Karampuang Island, as described above, shares these same characteristics. This has a negative impact on the process of food acquisition within the community. Moreover, Karampuang Island, like other coastal communities, maintains cultural values that grew out of their maritime, coastal and market-oriented society (Satria, 2001).

This study focused on island ecosystems, in this case Karampuang Island. Previous studies of the lives of fishermen generally emphasized their poverty and economic uncertainty; due to the life difficulties they faced (Kusnadi, 2000a; Pretty, Morison, \& Hine, 2003). This was triggerred by the uncertainty of the relationship between fishermen and their environment (Kusnadi, 2000a; Satria, 2009)

In order to maintain their livelihoods and well-being, the people of Pulau Karampuang have had to adapt to changing circumstances. In this case, adaptation refers to a reciprocal process between living things and their environment (Hardesty, 1977). Adaptation is a must for social systems to deal with their environment. They 
must adapt with the environment and adjust the environment in accordance with their needs (Ritzer \& Goodman, 2010).

\section{Methodology}

The paradigm applied in this study is the post-positivistic paradigm. The research design used in this study is descriptive with a combination approach called "qualitative dominant." This study, furthermore, uses a case study in order to look deeply into the social realities of institutional consumption and production in coastal areas.

Field data collection was conducted systemically through a questionnaire and indepth interviews. In addition, this research was supplemented by focus group discussions and field observations in order to better understand the real conditions of the community. There were two data sources, namely primary data and secondary data. Primary data, on one hand, were obtained from the community and the local government. The collected primary data included types of commodities cultivated, reasons those commodities were selected, types of consumed food, amount of consumed food, reasons for choosing food commodities, area of control, types of community work in the field, and the intensity of community's consumption. Secondary data were obtained from related literatures. The focus of the research was determined to be coastal communities which were selected based on the introductory studies of the field conditions and on initial information that had been previously obtained from key informants. Considering the limited funds, the range of research control area, the time, and energy, the target groups of the coastal communities were narrowed down into the inhabitants of Karampuang Island, who have been living with limited amount of food production in Mamuju Regency, West Sulawesi Province. This study applied a qualitative-data analysis, examining and describing patterns of food production and consumption in Karampuang Island. Karampuang Island is located at $118^{\circ} 52$ '00 "- 118 o 54 '00", East Longitude and 2० 36'30 "- 2 $2^{\circ} 40^{\prime} 00^{\prime}$ South Latitude, located politically within the Mamuju District, West Sulawesi Province. Situated in a large bay, the norther end of the island looks out upon the Makassar Strait, while the southern end of the island is about five kilometers north of Mamuju City. Across the water to the east lies the western part of Rangas Village, and to the west, the eastern part of Desa Bambu.

Geographically, Karampuang island is surrounded by coastal rocks and sandy beaches, although mangroves can still be seen growing as beach protection. The length of the coastline is approximately $9 \mathrm{~km}$. The topography of the island is dominated by low hills reaching a height of about 23 meters above sea level. The coastal sand has a rough structure, consisting of broken shells and dead Acropora corals. By administration, the village of Karampuang Island has 11 sub-districts, namely: Karampuang I, Karampuang II, Baja, Karaeng, Ujung Bulo, Sepang, Batu Bira, North Sepang, Gunung Gembira, Joli, and Nangka.

Karampuang Island is located in the western part of Mamuju Subdistrict. Karampuang is the closest island from the Capital of Mamuju Regency with a distance of approximately $5 \mathrm{~km}$, and is only reached by sea transportation with a travel time of approximately 20-25 minutes. The island has a moderate climate temperature ranging from $20{ }^{\circ} \mathrm{C}-34{ }^{\circ} \mathrm{C}$. Rainfall ranges from $93-1093 \mathrm{~mm} /$ year with the number of rainy days 11-17 days / month. The rainy season usually occurs from October to January while the dry season occurs from July to September. 
Education facilities in Pulau Karampuang are adequate, namely the availability of facilities ranging from Early Childhood Education (PAUD) to Secondary School. The facilities are detailed as follows: 1 unit PAUD (early childhood school), 3 Elementary Schools, namely Karaeang Public Elementary School, Karampuang Elementary School and Sepang Public Elementary School. Junior High Schools (SLTP), moreover, are Satu Atap Junior High School Karampuang and MTs Al Chairyah. Senior High Schools (SLTA) are located in the city of Mamuju. The current condition of community's education level can be seen in the following table:

Table 1. Population based on Education level in Karampuang Island

\begin{tabular}{clcc}
\hline Numb. & Education Level & $\begin{array}{l}\text { Number } \\
\text { (Population) }\end{array}$ & Percentage \\
\hline 1 & Not school yet & 1570 & 53.5 \\
\hline 2 & Kinder garten & 672 & 22.9 \\
\hline 3 & Elemntary School & 330 & 11.2 \\
\hline 4 & Junior High School & 244 & 8.3 \\
\hline 5 & Senior High School & 110 & 3.7 \\
\hline 6 & University Education & 11 & 0.4 \\
\hline & Total Number & 2.937 & 100 \\
\hline
\end{tabular}

Source : Analyzed Primary data, 2018

Based on the table above, it can be seen that the majority of people did not go to school or have not gone to school, or 53.5 percent of the whole population, while the smallest number had obtained higher education, or $0.4 \%$. Based on these numbers, it can be seen that the level of education in Karampuang island was still very low. One of the aggravating factors was the associated costs and limited education facilities in Karampuang Island, while those who want to study beyond the Junior High School level must leave the island for Mamuju City. For them, there is the additional transportation cost of crossing daily by boat.

\section{Results and Discussion}

\subsection{Adaptation Strategies for Food Production}

Competition over controlling resources will increase the workload of fishermen. Working as a fisherman can be seen as heavy occuption. However, fishermen cannot easily compete for other, easier jobs, as their skillset, often passed down through generations, is not easily transferable to other occupations. If a fisherman is able to provide a good education for his children, then the chance that the next generation will not become fishermen is increased. However, fishermen generally are not able to free themselves from their work as fishermen. On the other hand, many groups of fishermen are found to be able to survive even in very difficult conditions, especially during famine (Sastrawidjaja \& Manadiyanto, 2002).

The fishing communities in Indonesia are a group of people who are mostly regarded as poor, even viewed as the poorest among the poor (Muflikhati, 2010). The condition of fishermen, especially small-scale fishermen in Indonesia, is at a marginal level (Budi, 2008; Kusnadi, 2000b; Semedi, 2003). Generally, fishing communities still live within limitations both economic and social. These limitations include levels of income and the 
human resources of fishermen which are generally still low, especially when compared to communities other than fishermen (Wahyono A. et al, 2001).

Karampuang Island, as described above, has a limited capacity for food production, resulting in the inability to produce enough food independently. So in fulfilling food consumption needs, it is very vulnerable. This condition is caused by over fishing near the island, due primarily to frequent blast fishing and the use of modern fishing gear by fishermen from other regions and coastal reclamation.

Production sector activities carried out by people of Pulau Karampuang feature a division of labor between household leaders and housewives in an effort to survive and improve their life standards. The family leaders earned money by farming or catching fish, whereas housewives carried out tasks in harvesting activities, such as processing cassava own production for food and processing fishes and then selling them to market in Mamuju city. The aforementioned efforts are production activities in the agricultural sector. In addition, production activities carried out in the non-agricultural sector include both men and women working as laborers. This is similar to what is described by Alkhudri, Tarmiji, \& Zid (2016) who says that for poor households, the meaning of the double livelihood pattern is a life strategy where the outside, non-agricultural sector is an important source of income to cover the shortages of the agricultural sector.

The limited resources for production activities within the community in Karampuang Island required all existing family members to maximize their potential to obtain sources of income in fulfilling their daily needs. This is in line with opinion of Sajogyo (1983); White \& David M. Klein (2007), stating that working-age family members are involved in earning a living in various sectors, namely agriculture and non-agriculture, either establishing business or becoming laborers.

Food accessibility for the people on Karampuang Island was determined by several factors, namely: income, food and non-food prices, community employment opportunities, transportation facilities, supporting infrastructure of production, geographical conditions, and food assistance programs. The level of household income of Karampuang Island community can be seen in the following graph:

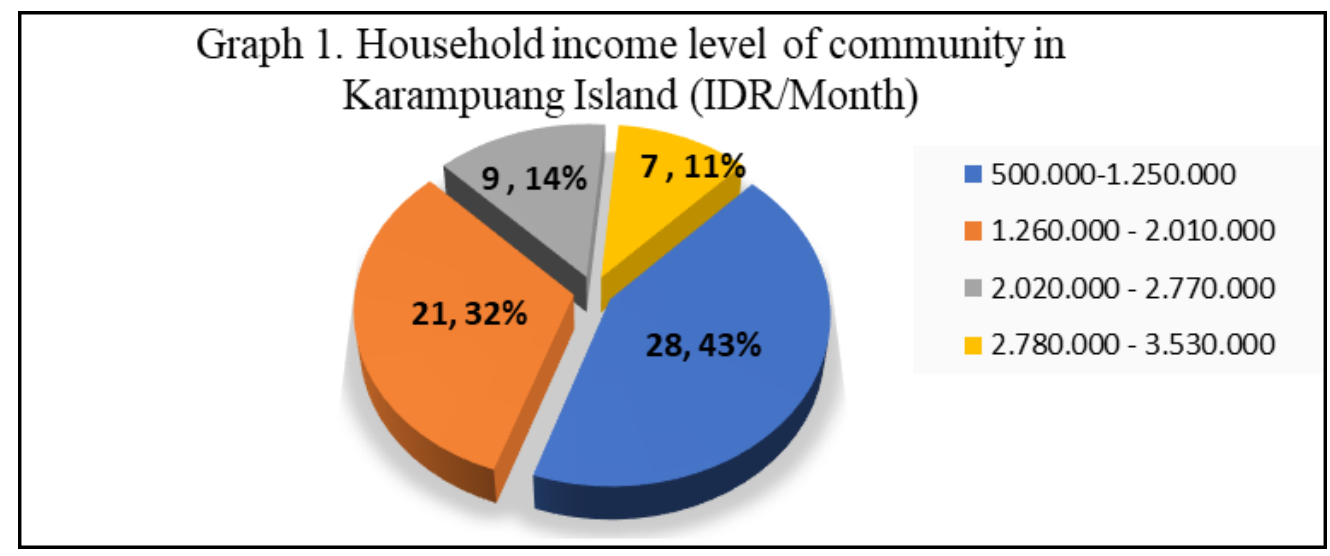

Source: Primary Data after analyses, 2018 
Based on the graph above, it can be seen that the income of people in Karampuang Island was mostly around IDR Rp. 500,000 - 1,250,000 for 28.43 percent of the households, and IDR Rp. 1,260,000-2,010,000 for 21.32 percent of the households. This suggests that residents of Karampuang Island can be still categorized as low income workers, making it difficult for them to access food at Mamuju Market. With this amount, most of the income must be allocated to buy food. This is in accordance with the study by Amaliah \& Handayani (2011), that pointed out that the low income of farmer families will have a negative impact, reducing opportunities to obtain good quality food. On the other hand, the higher the income of a household, the greater the level of accessibility in obtaining good food.

Food and non-food prices in Pulau Karampuang are generally fluctuating and likely to increase over time. This is based on recognition from respondents such as (NL, 44 years old):

"Dulu kalau kita ke pasar Mamuju, dengan membawa uang Rp. 100-200 ribu, maka sudah dapat membeli kebutuhan selama seminggu baik beras maupun sayur, telur dan kebutuhan bumbu dapur. Sedangkan sekarang kalau bawa uang sejumlah itu tidak dapat membeli semua kebutuhan dalam seminggu."

"If we went to Mamuju marker in the old time carrying IDR Rp. 100-200 thousand, it was possible to buy (basic) needs, such as rice and vegetables, eggs and kitchen spices, and enough for one week stock. Now, however, that amount of money will not be sufficient to buy the aforementioned needs in a week."

In terms of non-food materials purchased by people in Pulau Karampuang, it consisted of daily needs such as electricity and toilet supplies (e.g. soaps, toothpastes, shampoos). Incidental needs included clothes, school and education, health care, cost, medicines, celebrations, and Islamic charitable tax.

Table 2. Percentage of Expense Comparison for Foods and Non-Foods

\begin{tabular}{|c|c|c|}
\hline \multirow{2}{*}{ Percentage of Expense } & \multicolumn{2}{|c|}{ Number of Family } \\
\cline { 2 - 3 } & Foods & Non-Foods \\
\hline $0-20$ & 0 & 24 \\
\hline $21-40$ & 2 & 19 \\
\hline $41-60$ & 21 & 20 \\
\hline $61-80$ & 25 & 2 \\
\hline $81-100$ & 17 & 0 \\
\hline total & 65 & 65 \\
\hline
\end{tabular}

Source: Primary Data after analyzed, 2018

Based on the graph above, it can be said that the general expenditure of Karampuang Island for food needs ranged from 40 - 100 percent from the total household income, or an average of 69.0 percent each month. For non-food needs, on the other way around, ranged from 0 - 60 percent or an average of 31.0 percent from the total household income each month. This indicates that people of Karampuang Island still have a low level of wellbeing. This is based on the understanding that food expenditure is one indicator of food security, suggesting that the greater the share of expenditure for food, 
the lesser food security will be. On the other hand, the higher the welfare of a country, the smaller the share of food expenditure will be, (Deaton \& Muellbauer, 1980).

It was also found that with limited job opportunities on Karampuang Island, residents employed economic strategies in the form of a double income pattern through optimization of household labor and migration. In response to greater employment opportunities in Mamuju City, the dominant livelihood strategy is migration. Migrants are mostly dominated by a group of mothers and young people who dropped out of school. They are no longer interested in work in the fishing sector. The low income is one of their reasons for leaving this sector, one which has been running for a very long time. In addition, the attraction of city life cannot be denied as one triggering factor of migration.

The transportation facilities available on the island include boats and motorbikes. Boats are used both to connect one region to other regions on Karampuang Island and to connect to the City of Mamuju. This is because every day people travel to Mamuju City. For transportation in the Karampuang Island area, motorbikes are still the first option. The use of boats for people on Pulau Karampuang is very important as a means of transportation, both used for public transportation, fishing and for access to food and non-food items that are only available in Mamuju City.

The last factor regarding food accessibility is the food subsidy from the government. The food subsidy received by the community is "Rice for poor groups" (locally named as Raskin). It is a program of the Central Government, and it is very helpful for the community in fulfilling their food needs. As we learned from a respondent HD (56 years) below:

"Bantuan beras dari pak desa yang kami peroleh itu membantu sekali karena kadang kami kehabisan beras sedangkan uang tidak cukup membeli beras. Hanya saja sudah beberap bulan ini bantuan tidak ada lagi."

"The rice subsidy from the village leaders was very helpful for us, because sometimes we runout of rice stock while our money is not sufficient to purchase rice. However, it has been several months and we did not receive the rice subsidy yet."

An important change in consumption patterns from consuming cassava as a starch staple to consuming rice has been taking place over about 30 years. This change was enabled by the availability of rice for sale in Mamuju City. This changing behavior arose because of technological factors, such as advertisements that are meant to direct people's attentions towards new foods. Through advertisement, both printed and electronic media, people became interested in purchasing, in this case, rice. People's awareness is likely structured by the desires, dreams, and imagination fostered by messages conveyed by "signs" regarding food (e.g. food labels, advertisments, presentation in luxurious settings, and so on) (Widodo, 2011). The consumption behavior of people in Pulau Karampuang varies by several factors, as in the following:

a. Age factor

The Karampuang Island's inhabitants aged 35 and above likely preferred to consume cassava (Kalumpang) as their main food staple, although there was a small percentage who mixed cassava with rice as an additional food, as stated by a respondent JB (49 years): 
Kita ini yang tua masih suka makan kalumpang kalau makan malam dan bekal kalau ke laut masih kalumpang karena cocok dengan bau peapi (ikan masak)."

"Old groups still like eating cassava for dinner, and it is also cooked as food stock for sailing, since it is nice eaten with cooked fish."

On the other hand, people aged 35 years and under are likely to consume rice as the main food. This finding as based on an informant's statement NN (48 years):

"kebanyakan anak-anak yang lahir sesudah tahun 80-an itu sudah tidak suka kalumpang, mereka lebih suka nasi”.

"most of the children born after the 80 s do no prefer to eat kalumpang (cassava), they otherwise prefer to eat rice"

\section{b. Income Factor}

The level of income of the community in fact determined the tendency for what food ingredients to buy. People on Karampuang Island usually purchase groceries every week at the Mamuju market. The amount of money they spend depends on their weekly income. Based on this, it is divided into three categories, which are: 1) food consumed during a week was rice, 2) food consumed during a week combined rice and cassava, and 3) food consumed during a week was only cassava. The division of these three categories was caused by purchasing ability of food staples.

\section{c. Educational Factors}

The level of education is found to have played a very significant role in determining society's consumption behavior. This is in accordance with the study by (Syam, Hermanto, \& Musaddad, 1996), suggesting that the education of the household leaders has a significant effect on household food consumption behavior. Furthermore, higher levels of education will make it easier for someone to absorb information and implement changes in behavior and daily lifestyle, especially in terms of health and nutrition (Atmarita \& Fallah, 2004). food choices in society are more likely to be based on an understanding of the nutritional content of food. This was based on HD's (56 years) acknowledgment, saying that"

"Saya kalau ke pasar belanja, lebih dulu beli beras karena selain enak juga bergizi, itu yang saya tahu."

"If I go to the market, I prefer to buy rice because rice is tasty and nutritious; that's what I know."

Based on the aforementioned explanation, it can be summed up that the education of housewives highly determined their food choices, because those who purchased food were mostly housewives. The adaptation surrounding food consumption carried out by people on Karampuang island was more likely an effort to diversify consumption by converting from cassavas to rice as the starch staple. This is to adapt with the food availability. Cassava is a local food and rice as imported food from outside the island. Cassava was, in this case, the main food staple that has been continuosly consumed by the community since 1970 s. 


\section{Conclusion}

The food consumption pattern of people inhabiting Karampuang Island has change from cassava to rice since the 1970 s due to cyclical migration since the $1970 \mathrm{~s}$. In addition, government policies are also found to play a role in influencing people's consumption patterns.

The adaptation strategy for community's food production in Karampuang Island can be seen as an effort to survive through a double livelihood strategy. In this case, it optimally used the potentials of the household workers. Here, men are responsible for fishing in the sea and becoming laborers in Mamuju City while women are responsible for selling caugh fishes to Mamuju City, and working as laundry women or shopkeepers. The adaptation strategy of food consumption carried out by people in Karampuang island was by diversifying food between cassavas and rice.

\section{Acknowledgment}

We would like to express our deepest gratitude to Mr. Supriadi and all people in Karampuang Island for their kind assistance and participation in this current study.

\section{References}

Alkhudri, Tarmiji, A., \& Zid, M. (2016). Sosiologi Pedesaan, Teoritisasi dan Perkembangan Kajian Pedesaan di Indonesia. Jakarta: PT. RajaGrafindo Persada.

Ahmad, A., Rahmadanih, \& Ali, M. S. S. (2017). Patterns of Food Consumption and Production of Mountainous Community in Sinjai District, South Sulawesi Province , Indonesia. International Journal of Agriculture System (IJAS) Patterns, 5(1), 90100. https://doi.org/http://dx.doi.org/10.20956/ijas.v5i1.1175

Ali, M. S. S., Majjka, A. Am., \& Salman, D. (2017). Food Consumption and Production in Tempe Lake, South Sulawesi, Indonesia. Asian Rural Study, 1(1), 43-52.

Amaliah, \& Handayani. (2011). Analisis Hubungan Proporsi Pengeluaran Dan Konsumsi Pangan Dengan Ketahanan Pangan Rumah Tangga Petani Padi Di Kabupaten Klaten. SEPA, ISSN : 1829-9946, 7(2), 110 - 118.

Atmarita, \& Fallah, Y. (2004). Analisis Situasi Gizi dan Kesehatan. Jakarta: Science Department of Indonesia.

Budi, S. (2008). Kemiskinan dan Perlawanan Kaum Nelayan. Malang: Laksbang Mediatama.

Burnham, M., \& Ma, Z. (2017). Multi-Scalar Pathways to Smallholder Adaptation. World Development. https://doi.org/10.1016/j.worlddev.2017.08.005

Carletto, C., Zezza, A., \& Banerjee, R. (2013). Towards better measurement of household food security: Harmonizing indicators and the role of household surveys. Global Food Security, 2(1), 30-40. Deaton, A., \& Muellbauer, J. (1980). Economics and Consumer Behavior. England: Cambridge University Press.

Gerbens-Leenes, P., \& Nonhebel, S. (2002). Consumption patterns and their effects on land required for food. Ecological Economics, 42(1), 185-199. https://doi.org/10.1016/S0921-8009(02)00049-6

Hardesty. (1977). Ecological Anthropology. New York: Mc Graw-Hill.

Hernanto, F. (1996). Ilmu Usahatani. Jakarta: Penebar Swadaya. 
Krisnamurti, B. (2005). Perum Bulog Dan Kebijakan Pangan Indonesia: Kendaraan Tanpa Tujuan?

Kusnadi. (2000a). Nelayan: Strategi Adaptasi dan Jaringan Sosial. Bandung: Humaniora Utama Press.

Kusnadi. (2000b). Nelayan: Strategi Adaptasi dan Jaringan Sosial. Bandung: Humaniora Utama Press.

Muflikhati, I. (2010). Kondisi Sosial Ekonomi dan Tingkat Kesejahteraan Keluarga: Kasus di Wilayah Pasisir Jawa Barat. Jurnal Keluarga, 2-10.

Orlove, B. (2009). The past, the present and some possible futures of adaptation. In I. W. N. Adger, Lorenzoni, \& K. O'Brien (Eds.), Adapting to climate change: Thresholds, values, governance (pp. 131-163). Cambridge, UK: Cambridge University Press.

Osman, I., Osman, S., Mokhtar, I., \& Setapa, F. (2014). Family Food Consumption: Desire towards Convenient Food Products. Procedia - Social and Behavioral Sciences, 121, 223-231. https://doi.org/10.1016/j.sbspro.2014.01.1123

Pretty, J. N., Morison, J., \& Hine, R. E. (2003). Reducing food poverty by increasing agricultural sustainability in developing countries. Journal of Agriculture, Ecosystems and Environment, 95, 217-234.

Ritzer, G., \& .Goodman, D. J. (2010). Teori Sosiologi Modern. Yogyakarta: Kreasi Wacana.

Sajogyo. (1983). Peranan Wanita dalam Pembangunan Masyarakat Sosial. Jakarta: Private Institution of Social Sciences.

Sastrawidjaja, \& Manadiyanto. (2002). Nelayan Nusantara. Jakarta: Center of Research and Production and Social-Economical Coast and Fishing.

Satria, A. (2001). Dinamika modernisasi perikanan: formasi sosial dan mobilitas nelayan (1st ed.). Bandung: Humaniora Utama Press.

Satria, A. (2009). Ekologi Politik Nelayan. (A. Solihin, Ed.) (1st ed.). Yogyakarta: LKIS Printing Cemerlang.

Semedi, P. (2003). Close to the stone, far from the throne: The story of a Javanese community 1820s-1990s. Yogyakarta: Benang Merah.

Sulaiman, Ali, M. S. S., \& Salman, D. (2018). Food Production And Consumption Pattern At Coastal Area Of Karampuang Island, 2(2), 196-204. Retrieved from http://pasca.unhas.ac.id/ojs/index.php/jars/article/view/1510

Sulistyowati, L. (2003). Analisis Kebijakan Pemberdayaan Masyarakat Dalam Pengelolaan Sumber Daya Alam Gugus Kepulauan (Studi kasus Kelurahan Pulau Kelapa dan Kelurahan Pulau Harapan Kecamatan Kepulauan Seribu Utara, Taman Nasional Laut Kepulauan Seribu. Bogor Agriculture Institute.

Suryana, A. (2011). Rencana Aksi Nasional Pangan dan Gizi. Jakarta: Ministry of Nasional Development Planning/Bappenas.

Wahyono A. dkk. (2001). Pemberdayaan Masyarakat Nelayan. Yogyakarta: Media Pressindo.

White, J. M., \& David M. Klein. (2007). Family Theories, An Introduction (3rd Editio). New Delhi: Saga Publication, Inc.

Widodo, S. (2011). Strategies of Sustainable Livelihood for Poor Household in Coastal Area. Makara, Sosial Humaniora, 15(1), 10-20. 